\title{
Working together to improve lives in the Eastern Mediterranean Region
}

\author{
Ahmed Al-Mandhari ${ }^{1}$
}

${ }^{1}$ Regional Director, WHO Regional Office for the Eastern Mediterranean, Cairo, Egypt

Citation: Al-Mandhari A. Working together to improve lives in the Eastern Mediterranean Region. East Mediterr Health J. 2018;24(6):503. (https://doi. $\operatorname{org} / 10.26719 / 2018.24 .6 .503$

Copyright (c) World Health Organization (WHO) 2018. Some rights reserved. This work is available under the CC BY-NC-SA 3.0 IGO license (https:// creativecommons.org/licenses/by-nc-sa/3.o/igo).

It was an immense honour when the World Health Organization Regional Office for the Eastern Mediterranean (WHO/EMRO) welcomed me as its new Regional Director on 1 June 2018. On this occasion, I would like to extend my sincere thanks and appreciation to the members of the WHO Executive Board during its 143rd session in Geneva, Switzerland, for giving me an opportunity to propose my agenda for change towards a stronger and healthier Region (1). I look forward to my tenure as Regional Director, and have been impressed by the support displayed by WHO/EMRO staff, the WHO Executive Board, and public health bodies further afield.

As a family physician and specialist in quality healthcare provision and management, the pressures and challenges facing the Eastern Mediterranean Region (EMR) resonate strongly with my desire to tackle these difficulties and see measurable improvement in the health of people in our Member States, and listen to their concerns. It is clear to all that the Region is passing through a critical era, marked by natural and manmade crises that have led to destruction of infrastructure and a deterioration in the health and living conditions of many people, particularly displaced populations and refugees. Thus, every effort must be made and all available resources mobilized to find appropriate solutions to these challenges.

As I take up the role of Regional Director, my immediate priority is to begin working with countries in order to bring WHO closer to its Member States. No tangible change can be made if we are far away from the areas where change is needed. The work and policies already undertaken and approved by WHO have immense applicability to the needs of the EMR; in particular the United Nation's Sustainable Developmental Goal of Universal Health Coverage (2), the International Health Regulations (2005) (3), and WHO's Thirteenth General Programme of Work 2019-2023 (4), which are among the key forces that I seek to promote in order to drive interventions during my term as Regional Director.

Further to these key forces, I have identified four priority technical areas for my agenda, which are: tackling health emergencies including disease outbreaks; improving control of communicable and noncommunicable diseases and their risk factors; strengthening health systems to achieve universal health coverage through a primary health care approach, with special emphasis on family practice; and improving maternal and child health.

However, it is important to remember that tackling degradation in public health in the Region is a collaborative effort. The Organization has a wealth of experience and expertise that has been demonstrated over decades. Together in partnership with our other United Nations agencies, developmental partners and nongovernmental organizations, no effort should be spared to strengthen coordination and collaboration mechanisms to the benefit and efficiency of operations in the Region. Ultimately my goal is to see WHO full of life, energy and enthusiasm. I would like to see staff at different levels of this Organization working together as a strong, productive team to provide the highest level of support to Member States, which turn to us for assistance in the drive to improve the lives of ordinary citizens that have found themselves desperate through no fault of their own.

I am immensely humbled by my selection as Regional Director, and look forward to working with all WHO staff and our partners in our collective effort to raise the quality of public health in the EMR. We are all aware of the steep challenges facing us, but I am confident after having witnessed the dedication and experience of EMRO staff that we can together make a noticeable difference to the lives of many.

\section{References}

1. World Health Organization. 143rd session of the Executive Board. Geneva: World Health Organization; 2018 (http://www.who.int/ news-room/events/detail/28/05/2018/default-calendar/143rd-session-of-the-executive-board).

2. World Health Organization. SDG 3: Ensure healthy lives and promote wellbeing for all at all ages. Geneva: World Health Organization; 2016 (http://www.who.int/sdg/targets/en/)

3. World Health Organization. International Health Regulations (2005). Geneva: World Health Organization; 2016 (http://www.who. int/ihr/publications/9789241580496/en/).

4. World Health Organization. Thirteenth general programme of work 2023-2019. Geneva: World Health Organization; 2017 (http:// www.who.int/about/what-we-do/gpw-thirteen-consultation/en/). 